\title{
Space-based observation of volcanic iodine monoxide
}

\author{
Anja Schönhardt ${ }^{1}$, Andreas Richter ${ }^{1}$, Nicolas Theys ${ }^{2}$, and John P. Burrows ${ }^{1}$ \\ ${ }^{1}$ Institute of Environmental Physics, University of Bremen, Otto-Hahn-Allee 1, 28359 Bremen, Germany \\ ${ }^{2}$ Belgian Institute for Space Aeronomy, Avenue Circulaire 3, 1180 Brussels, Belgium \\ Correspondence to: Anja Schönhardt (schoenhardt@iup.physik.uni-bremen.de)
}

Received: 13 July 2016 - Discussion started: 22 July 2016

Revised: 24 February 2017 - Accepted: 8 March 2017 - Published: 13 April 2017

\begin{abstract}
Volcanic eruptions inject substantial amounts of halogens into the atmosphere. Chlorine and bromine oxides have frequently been observed in volcanic plumes from different instrumental platforms such as from ground, aircraft and satellites. The present study is the first observational evidence that iodine oxides are also emitted into the atmosphere during volcanic eruptions. Large column amounts of iodine monoxide, IO, are observed in satellite measurements following the major eruption of the Kasatochi volcano, Alaska, in 2008. The IO signal is detected in measurements made both by SCIAMACHY (Scanning Imaging Absorption Spectrometer for Atmospheric CHartographY) on ENVISAT (Environmental Satellite) and GOME-2 (Global Ozone Monitoring Experiment-2) on MetOp-A (Meteorological Operational Satellite A). Following the eruption on 7 August 2008, strongly elevated levels of IO slant columns of more than $4 \times 10^{13} \mathrm{molec}^{-2}$ are retrieved along the volcanic plume trajectories for several days. The retrieved IO columns from the different instruments are consistent, and the spatial distribution of the IO plume is similar to that of bromine monoxide, BrO. Details in the spatial distribution, however, differ between $\mathrm{IO}, \mathrm{BrO}$ and sulfur dioxide, $\mathrm{SO}_{2}$. The column amounts of IO are approximately 1 order of magnitude smaller than those of BrO. Using the GOME-2A observations, the total mass of IO in the volcanic plume injected into the atmosphere from the eruption of Kasatochi on 7 August 2008 , is determined to be on the order of $10 \mathrm{Mg}$.
\end{abstract}

\section{Introduction}

Halogen oxides strongly influence atmospheric composition. Catalytic reaction cycles involving chlorine, bromine or iodine, lead to ozone depletion in the troposphere. In the stratosphere, the role of chlorine and bromine, which are released predominantly as a consequence of anthropogenic emissions of chlorofluorocarbon compounds, is well established (World Meteorological Organization, 2014). The potential importance of iodine reactions for stratospheric ozone depletion is discussed in Solomon et al. (1994), Hossaini et al. (2015), and Saiz-Lopez et al. (2015a).

Stratospheric concentrations of iodine species are much lower than those of chlorine and bromine compounds (Bösch et al., 2003; Butz et al., 2009). From balloon-borne observations, an upper limit for stratospheric iodine monoxide, IO, of 0.1 parts per trillion by volume (pptv) was determined in the tropics (Butz et al., 2009), while upper limits for IO of $0.2 \mathrm{pptv}$ at $20 \mathrm{~km}$, or $0.1 \mathrm{pptv}$ at $15 \mathrm{~km}$, were derived in the mid- and high latitudes (Pundt et al., 1998). Butz et al. (2009) estimate upper limits of total gaseous iodine of about 0.09 to $0.16 \mathrm{pptv}$ in the tropical lower stratosphere (21.0 to $16.5 \mathrm{~km})$ and 0.17 to $0.35 \mathrm{pptv}$ in the tropical upper troposphere (16.5 to $13.5 \mathrm{~km}$ ). A recent study by Saiz-Lopez et al. (2015a) estimates that stratospheric iodine may range between 0.25 $0.7 \mathrm{pptv}$. This is based on, for example, new aircraft observations in the tropics from which volume mixing ratios (VMRs) of IO between $0.1-0.2 \mathrm{pptv}$ at altitudes up to $14 \mathrm{~km}$ were retrieved (Volkamer et al., 2015).

The ozone destruction potential of stratospheric iodine is significantly higher than that of the other halogens. Bromine is about 60 times more effective in destroying ozone than chlorine and, for iodine, the factor is about 150 to 300 
(World Meteorological Organization, 2014). The effective chain length of the catalytic cycles involving iodine and IO is larger than those involving the other halogens. This is in part because the temporary reservoir species containing iodine are photolysed and/or react more rapidly with stratospheric free radicals than their chlorine or bromine analogues. As a result, reactive iodine may impact stratospheric ozone chemistry (Solomon et al., 1994; Hossaini et al., 2015) even at sub-pptv levels.

IO is formed by the reaction of iodine radicals with ozone, $\mathrm{O}_{3}$. Catalytic cycles including $\mathrm{IO}$, by which tropospheric $\mathrm{O}_{3}$ is effectively destroyed, were already proposed in the 1980s (Chameides and Davis, 1980). As a result of self reactions, iodine oxides may lead to particle formation and thereby affect atmospheric radiation balance (Burkholder et al., 2004; O'Dowd and Hoffmann, 2005; Saunders et al., 2010). These effects of iodine motivate the scientific interest in the assessment of sources, amounts and distributions of iodine species in the atmosphere.

Atmospheric iodine is of organic as well as inorganic origin, e.g. from emissions of $\mathrm{I}_{2}$ and of halogenated organic compounds such as $\mathrm{CH}_{3} \mathrm{I}$ and $\mathrm{CH}_{2} \mathrm{I}_{2}$ (Saiz-Lopez et al., 2012, and references therein). The largest iodine sources in general are the world's oceans. Iodine compounds are emitted into the marine boundary layer, e.g. from algae (Schall et al., 1994; Alicke et al., 1999; Carpenter, 2003) or via inorganic pathways involving the ocean surface (Garland and Curtis, 1981; Carpenter et al., 2013). In the polar troposphere, bromine and iodine oxides are both observed predominantly during spring time. Release mechanisms of iodine and bromine above sea ice areas, however, are considerably different. Bromine monoxide, $\mathrm{BrO}$, is released following an autocatalytic Br activation (Vogt et al., 1999), also known as the bromine explosion mechanism. Iodine most probably takes different pathways involving the release of organoiodine compounds (Saiz-Lopez et al., 2015b), while inorganic reactions cannot be excluded.

Volcanic eruptions are an important source of halogens in the atmosphere, especially for the free and upper troposphere and the lower stratosphere (von Glasow et al., 2009). Volcanic plumes are known to contain halogen species initially in acidic form, e.g. $\mathrm{HF}, \mathrm{HCl}, \mathrm{HBr}$ and $\mathrm{HI}$ (Aiuppa et al., 2009). Bromine oxides as well as chlorine oxides have been previously observed in volcanic plumes. Volcanic $\mathrm{BrO}$ was first detected by Bobrowski et al. (2003), who applied the well-established Differential Optical Absorption Spectroscopy (DOAS) technique (Platt and Stutz, 2008) with a ground-based Multi-Axis DOAS (MAX-DOAS) system. Volcanic chlorine oxides, $\mathrm{ClO}$ and $\mathrm{OClO}$, were also measured, e.g. by Lee et al. (2005) and Bobrowski et al. (2007), using ground-based DOAS instruments. From space, volcanic $\mathrm{BrO}$ was detected for the first time from the Kasatochi eruption in 2008 (Theys et al., 2009), followed by volcanic OClO from the Puyehue eruption in 2011 (Theys et al., 2014). Several further observations using ground-based mea- surements (Bobrowski et al., 2006; Bobrowski and Platt, 2007; Kern et al., 2009), airborne instrumentation (General et al., 2015) as well as satellites (Hörmann et al., 2013) have confirmed and further quantified the abundances of bromine oxides injected into the atmosphere following volcanic eruptions. The release mechanism of volcanic $\mathrm{BrO}$ is believed to be similar to polar tropospheric $\mathrm{BrO}$ and is based on an autocatalytic reaction cycle involving volcanic aerosols (Bobrowski et al., 2007). Ozone depletion was observed within volcanic plumes and is attributed to reactive halogen chemistry (Lee et al., 2005; Surl et al., 2015, and references therein).

Using filter techniques, measurements at Mt Etna in Italy (Aiuppa et al., 2005) and at the Masaya and Telica volcanos in Nicaragua (Witt et al., 2008), for example, showed that gaseous $\mathrm{HI}, \mathrm{I}$ and $\mathrm{HBr}$ are relevant constituents in the degassing of these specific volcanos. Only a few studies are available that report on the analysed iodine content in samples of volcanic gases or volcanic fluids. Snyder and Fehn (2002) investigated the ${ }^{129} \mathrm{I} / \mathrm{I}$ ratio in volcanic fluids in order to determine the ages of iodine species. The determined iodine ages are in agreement with the expected age of subducted sediments. An iodine accumulation takes place here, because marine sediments contain concentrated amounts of organic iodine. Iodine oxides have not been previously detected in the emission plumes of volcanos. Gliß et al. (2015) report an upper limit for IO slant columns of 7.6 to $8.6 \times 10^{12}$ molec cm $^{-2}$ based on the detection limit of their ground-based DOAS observations at Mt Etna, Italy, during a stable quiescent degassing phase in September 2012.

The composition of volcanic gases is in general strongly variable, with individual characteristics changing from volcano to volcano as well as between eruption and degassing phases (Witt et al., 2008; Aiuppa et al., 2009, and references therein). While the gas-phase composition is individual for each volcanic eruption, there is also a general difference between iodine and other halogens in volcanic gases at high temperatures. At around $1000^{\circ} \mathrm{C}$, the main constituents are $\mathrm{HF}, \mathrm{HCl}$ and $\mathrm{HBr}$ for the other halogens. For iodine, however, $\mathrm{HI}$ and atomic I may be present in equal amounts (Aiuppa et al., 2005).

Up to the present, no detection of gaseous iodine oxides of volcanic origin has been reported, either by in-situ measurements or by remote sensing from ground or satellite. Iodine monoxide is retrieved from satellite measurements of backscattered solar radiation by the DOAS technique and is observed, for example, in the south polar region (Saiz-Lopez et al., 2007; Schönhardt et al., 2008, 2012). In most cases, atmospheric amounts of IO are fairly small, so that usually temporal averages of the satellite data of at least 1 month are created in order to improve signal-to-noise ratio.

In August 2008, the eruption of the Kasatochi volcano took place (Waythomas et al., 2010). Kasatochi belongs to the volcanic arc of the Aleutian Islands, Alaska. The violent explosions started on 7 August 2008, in the afternoon. 
The Volcanic Explosivity Index (VEI) (Newhall and Self, 1982), which classifies the eruptive volume and eruption cloud height, was VEI 3-4. Large amounts of ash and sulfur dioxide, $\mathrm{SO}_{2}$, were released into the atmosphere, reaching the lower stratosphere (Waythomas et al., 2010). In total about $1.7 \mathrm{Tg}$ of $\mathrm{SO}_{2}$ were emitted and spread over large parts of the globe.

In the following, the detection of IO from the eruption of the Kasatochi volcano using observations of the SCIAMACHY (Scanning Imaging Absorption Spectrometer for Atmospheric CHartographY) and GOME-2A (Global Ozone Monitoring Experiment-2A) satellite instruments is presented and discussed. The applied instruments and retrieval settings are briefly described, and the IO spectral fit quality is investigated. The IO results are analysed in terms of spatial distribution, temporal evolution and integral amount. In addition, $\mathrm{IO}$ and $\mathrm{BrO}$ distributions in the volcanic plume are compared among each other and to those of $\mathrm{SO}_{2}$.

\section{Instruments and Measurements}

The only satellite-borne spectrometer for which an IO product has been reported so far is the SCIAMACHY instrument onboard the European Environmental Satellite (ENVISAT) (Saiz-Lopez et al., 2007; Schönhardt et al., 2008, 2012). The mission operated between March 2002 and April 2012. In the present study, data from the GOME-2A onboard MetOpA (Meteorological Operational Satellite A) have also been successfully analysed, and the signatures of $\mathrm{IO}$ and $\mathrm{BrO}$ absorption have been retrieved. IO detection by GOME-2A is reported here for the first time. The DOAS method is used for the retrieval of trace gas amounts.

\subsection{Satellite instruments and data}

SCIAMACHY is a spectrometer measuring direct, scattered and reflected sunlight in the UV, visible and near-IR spectral regions. The spectra are measured contiguously from 214 to $1773 \mathrm{~nm}$ and in two spectral bands within the ranges of 1934-2044 and 2259-2386 nm. The operation modes include nadir, limb and occultation geometries (Burrows et al., 1995; Bovensmann et al., 1999; Gottwald and Bovensmann, 2011). The present study uses the nadir observations. ENVISAT has a Sun-synchronous, near-polar orbit with a local equator crossing time of 10:00 a.m. in descending node. Individual SCIAMACHY ground pixels in the spectral range used here have a typical size of $30 \times 60 \mathrm{~km}^{2}$. For the IO retrieval in general, spatial averaging over four ground pixels is applied to reduce noise. A further reduction in spatial resolution occurs for some parts of each orbit as a result of using the SCIAMACHY read-out from cluster 14 in channel 3 (404$424 \mathrm{~nm}$ ) in addition to the more commonly used cluster 15 (424-527 nm). Cluster 14 has a partly longer integration time than cluster 15, and the integration time is adapted for the

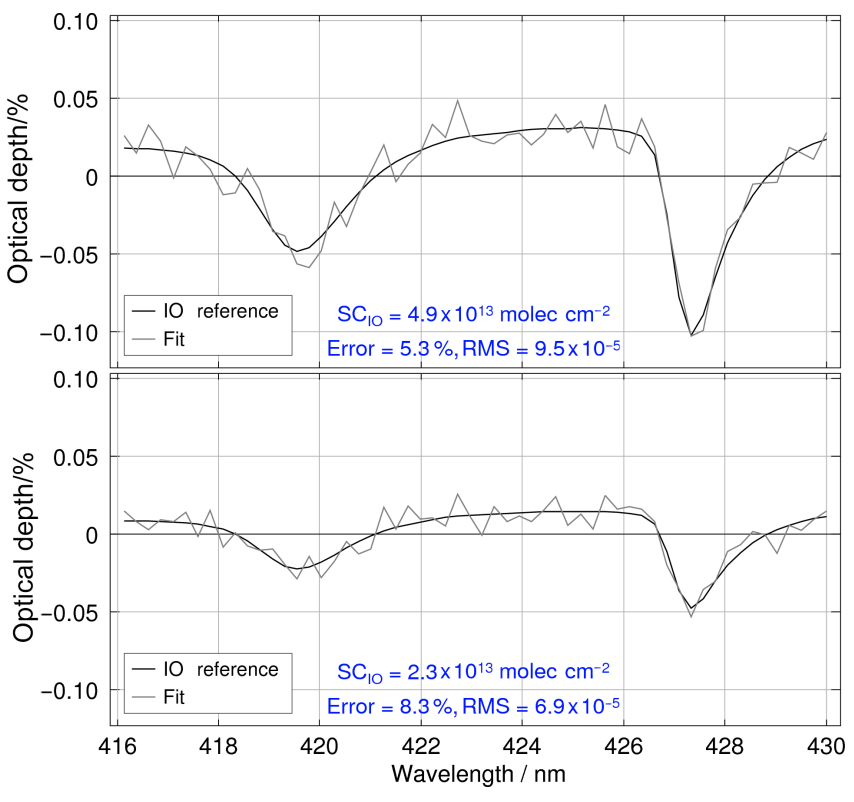

Figure 1. Example fitting results from SCIAMACHY on day 11 August 2008, with two different IO slant column amounts recorded at $55.34^{\circ} \mathrm{N}, 220.21^{\circ} \mathrm{E}$ (top) and $54.90^{\circ} \mathrm{N}, 215.92^{\circ} \mathrm{E}$ (bottom). The fit (grey) shows the measurement optical depth after all other features except for the IO absorption (black) have been subtracted. The optical depth RMS values are 9.5 and $6.9 \times 10^{-5}$, respectively.

entire spectral region to achieve smoothed spectra across the cluster border. The largest across-track ground-scene pixel size is $240 \mathrm{~km}$.

The GOME-2A instrument observes in the UV and visible spectral regions from 240 to $790 \mathrm{~nm}$ and performs measurements in nadir viewing geometry. Launched in July 2006 onboard MetOp-A, GOME-2A is the first of three nearly identical instruments. The mission officially started in October 2006, and data is available since January 2007. The equator crossing time of MetOp-A is 09:30 a.m. As for SCIAMACHY, spatial averaging is applied for the GOME-2A data in order to achieve noise reduction. The typical ground pixel size of $40 \times 80 \mathrm{~km}^{2}$ is thus increased to $80 \times 160 \mathrm{~km}^{2}$. For some direct comparisons with $\mathrm{BrO}$, however, the IO results without spatial averaging are used.

\subsection{DOAS retrievals of $\mathrm{IO}$ and $\mathrm{BrO}$}

The DOAS method is applied to the satellite measurements in order to retrieve $\mathrm{IO}$ and $\mathrm{BrO}$ column amounts. For the SCIAMACHY IO product, the standard retrieval settings as published in Schönhardt et al. (2008) and summarized in Table 1 are used. Two example fitting results from day 11 August 2008 are displayed in Fig. 1, showing the spectral fits for IO columns of $4.9 \times 10^{13} \mathrm{molec} \mathrm{cm}^{-2}$ (top) and $2.3 \times 10^{13} \mathrm{molec}^{-2}$ (bottom). The comparably large IO column amounts are detected with rather small relative fitting errors of 5.3 and $8.3 \%$, respectively. 
Table 1. Retrieval settings for IO from SCIAMACHY and GOME-2A observations.

\begin{tabular}{llll}
\hline Retrieval settings & SCIAMACHY & GOME-2A 2T & GOME-2A 3T \\
\hline Fitting window & $416-430 \mathrm{~nm}$ & $416-430 \mathrm{~nm}$ & $418-438 \mathrm{~nm}$ \\
Polynomial degree & 2 (quadratic) & 2 (quadratic) & 3 (cubic) \\
Trace gases & $\mathrm{NO}_{2}, \mathrm{O}_{3}$ & $\mathrm{NO}_{2}, \mathrm{O}_{3}$ & $\mathrm{NO}_{2}, \mathrm{O}_{3}, \mathrm{O}_{4}$ \\
& $\mathrm{IO}$ & $\mathrm{IO}$ & $\mathrm{IO}$ \\
Other features & Ring effect: SCIATRAN calculation (Rozanov et al., 2014; Vountas et al., 1998) \\
& Linear intensity offset correction \\
Background & Daily earthshine, Siberia $\left(60-70^{\circ} \mathrm{N}, 80-120^{\circ} \mathrm{E}\right)$ \\
\hline
\end{tabular}

For the analysis of GOME-2A data, two alternative retrievals are used and are also listed in Table 1 . The $2 \mathrm{~T}$ retrieval corresponds to the standard SCIAMACHY IO retrieval and therefore covers the same two IO transition bands. The GOME-2A data show higher noise levels than the respective SCIAMACHY measurements. Consequently, for the analysis of GOME-2A data, the use of more spectral information from a larger fitting window is investigated. The resulting $3 \mathrm{~T}$ retrieval covers three transition bands of the IO absorption spectrum. For SCIAMACHY, the 3T retrieval was not successful (Schönhardt et al., 2008) due to instrumentrelated spectral features above $430 \mathrm{~nm}$. It leads, however, to an improved quality of the IO retrievals from GOME-2A measurements. If not specified elsewise, in the following, GOME-2A IO results from the 3T retrieval are used. In terms of IO amounts, the results are consistent within the uncertainties between both GOME-2A retrievals as well as between GOME-2A and SCIAMACHY, cf. Sect. 3.2.

For all IO retrievals, a daily averaged earthshine spectrum is used as reference background. This background spectrum is generated from a reference area 60 to $70^{\circ}$ north and 80 to $120^{\circ}$ east - a continental region which is likely to contain only small column amounts of IO. Consequently, a differential slant column between the specific location and this reference region is retrieved.

The cross sections used for SCIAMACHY retrievals are $\mathrm{NO}_{2}(223 \mathrm{~K})$ (Bogumil et al., 2003) and $\mathrm{O}_{3}(223 \mathrm{~K})$ (Bogumil et al., 2003). For GOME-2A retrievals, $\mathrm{NO}_{2}(223 \mathrm{~K})$ and $\mathrm{O}_{3}(223 \mathrm{~K})$ from measurements with the GOME-2 flight model are used (Chehade et al., 2013, and P. Spietz, personal communication, 2005) as well as $\mathrm{O}_{4}$ (Greenblatt et al., 1990), with the latter only for the GOME-2A 3T retrieval. The absorption structures in the $\mathrm{O}_{4}$ spectrum are small in the spectral range of the IO fitting window and, in addition, these small structures differ rather strongly between the three available $\mathrm{O}_{4}$ cross sections in the literature (Greenblatt et al., 1990; Thalman and Volkamer, 2013; Hermans, unpublished data, http://spectrolab.aeronomie.be/o2.htm). However, the inclusion of any of the three $\mathrm{O}_{4}$ cross sections or completely omitting $\mathrm{O}_{4}$ from the $\mathrm{IO}$ retrieval has no significant influence on the resulting IO slant columns in the volcanic plume. For all retrievals, the IO $(298 \mathrm{~K})$ cross section measured by
Gómez Martín et al. (2007) is applied, convolved with the slit function of the respective instrument.

$\mathrm{BrO}$ columns are retrieved from GOME-2A in a fitting window from 336 to $347 \mathrm{~nm}$, taking into account absorption features of $\mathrm{O}_{3}(223$ and $273 \mathrm{~K}), \mathrm{NO}_{2}(223 \mathrm{~K})$ and $\mathrm{BrO}(\mathrm{Be}-$ goin et al., 2010). A cubic polynomial with four coefficients is fitted for the broadband spectral effects.

SCIATRAN calculations (Rozanov et al., 2014) are used to determine reference spectra for rotational Raman scattering (Ring effect), which is taken into account in all retrievals. An additional additive intensity offset compensates for effects such as stray light or different types of inelastic scattering, e.g. not fully compensated Ring structures, the influence of vibrational Raman scattering, VRS, in air (Lampel et al., 2015) and VRS on liquid water or liquid water absorption (Peters et al., 2014). Including VRS spectra of $\mathrm{N}_{2}$ and $\mathrm{O}_{2}$ explicitly in the IO retrieval does not change the resulting IO slant columns significantly.

The DOAS analysis yields the differential trace gas slant column amounts, which are the differences between two spectra in absorber concentrations integrated along the mean light path. In order to convert these slant column amounts into vertical column amounts, the air mass factor (AMF), i.e. the ratio between the slant and vertical column, is computed. For both IO and BrO, a geometric AMF is applied here which is suitable for a stratospheric absorber. For the current study, assuming a geometric AMF is adequate since the volcanic plume is located at fairly high altitudes (Theys et al., 2009) and the relevant solar zenith angle is below $50^{\circ}$. The influence of aerosols on light scattering and thus on the AMF is not considered in this work. Aerosols can increase or decrease visibility of trace gases depending on several aspects such as aerosol characteristics and the relative altitude distributions. Here we concentrate on a more qualitative discussion of the observed halogen amounts and distributions.

\section{Results}

\subsection{Observation of volcanic IO}

After the eruption of Kasatochi, enhanced IO column amounts are detected within the volcanic plume for several 

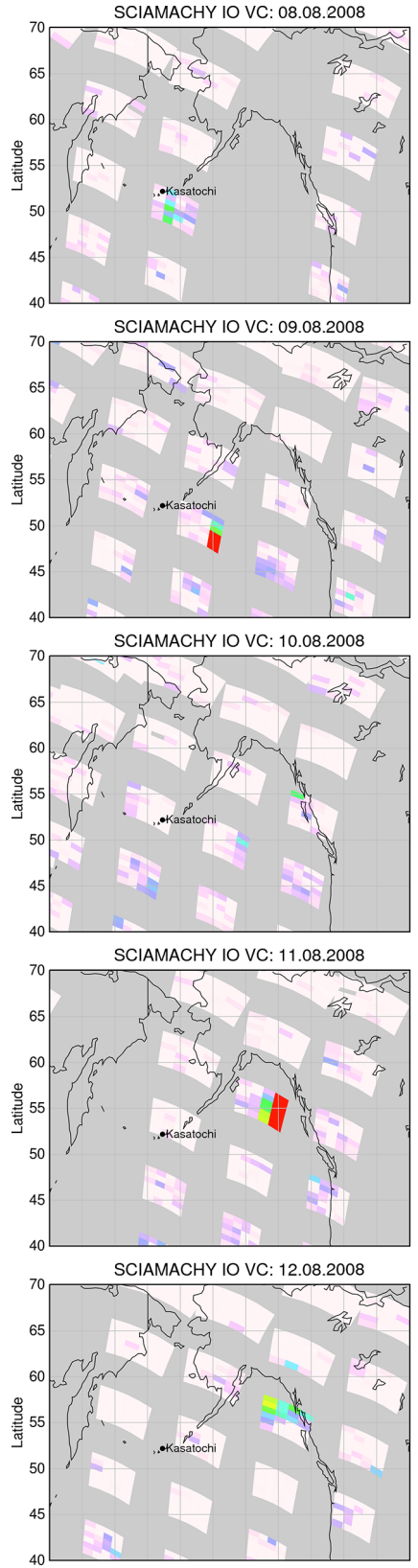

SCIAMACHY IO VC: 13.08 .2008

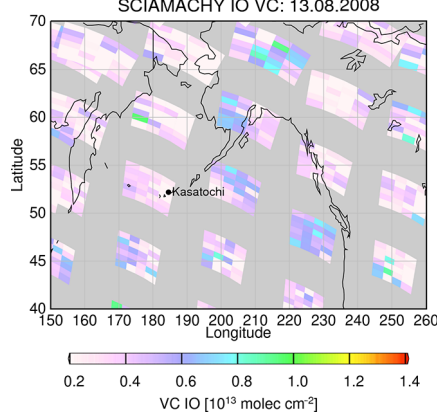

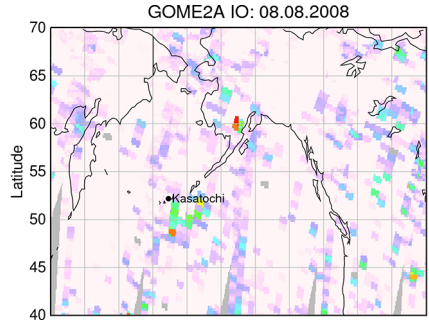

GOME2A IO: 09.08.2008

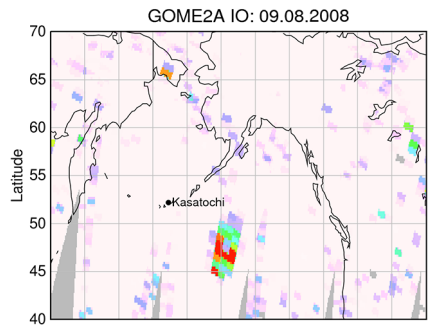

GOME2A IO: 10.08.2008
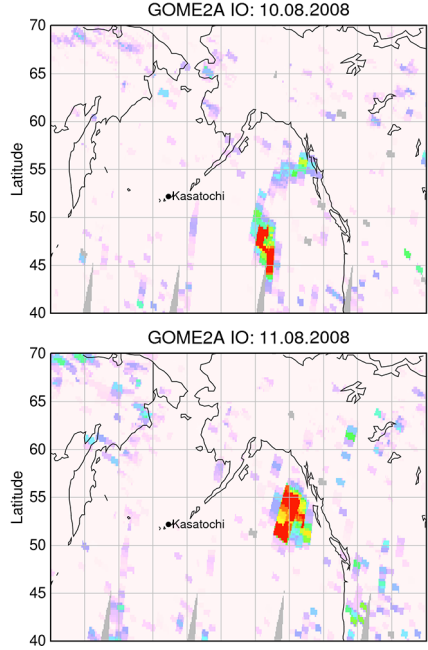

GOME2A IO: 12.08 .2008
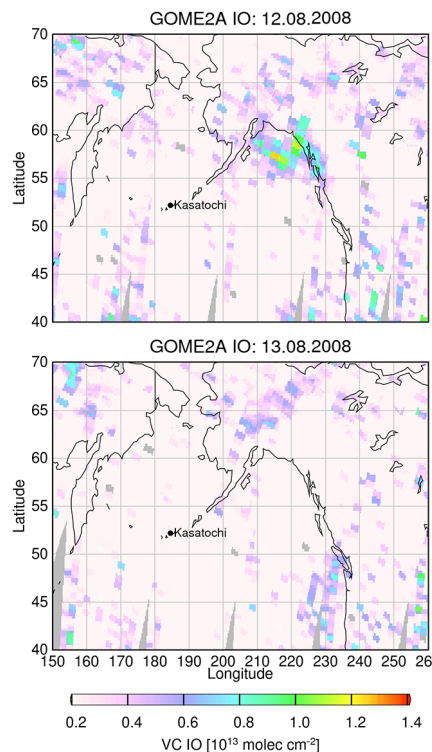

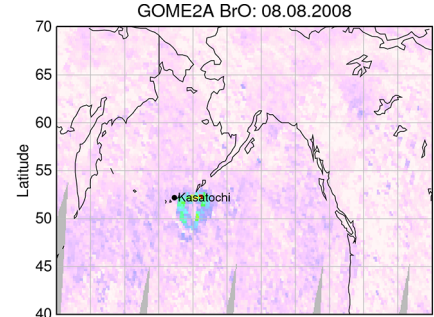

GOME2A BrO: 09.08.2008
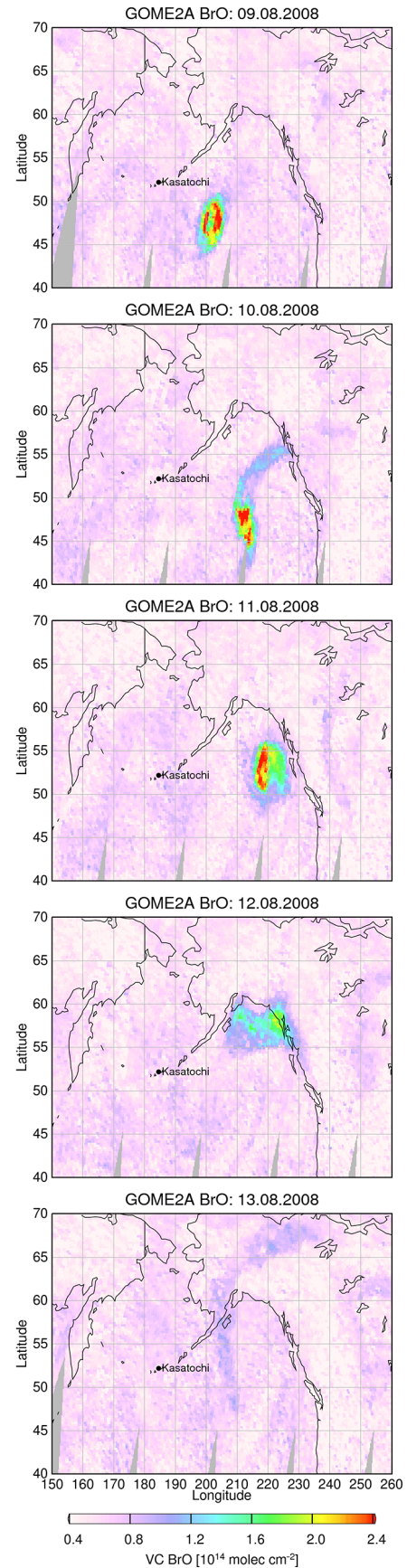

Figure 2. Retrievals of IO from SCIAMACHY (left) and GOME-2A (middle) together with observations of BrO from GOME-2A (right) for 6 days following the eruption of the Kasatochi volcano on 8 August 2008. Regions without data coverage are shaded in grey. 
days. As a consequence of the morning overpass times of the satellite instruments, the eruption, which started in the afternoon of 7 August 2008, can be observed from 8 August 2008 onwards. In Fig. 2, left column, the observational results from the SCIAMACHY IO retrieval are shown for 6 days from 8 to 13 August 2008. IO enhancements are detected on all 6 days as well as enhancements of $\mathrm{BrO}$ (not shown, see http://www.iup.uni-bremen.de/doas/scia_data_browser.htm? gas $=$ bro $\&$ column $=$ strat $\&$ view $=$ nh $\&$ year $=2008 \&$ month $=$ $8 \&$ day $=8$ ). On 8 August, a loop-shaped area with enhanced IO is visible, and maximum slant column amounts are around $2.3 \times 10^{13}$ molec $\mathrm{cm}^{-2}$. In the same area, BrO reaches slant column values up to $4.2 \times 10^{14}$ molec $\mathrm{cm}^{-2}$. The slant column amounts on 9 August are higher, with $3.4 \times 10^{13}$ and $5.6 \times 10^{14}$ molec $\mathrm{cm}^{-2}$ for IO and $\mathrm{BrO}$, respectively. While on day 10 August the volcanic plume is situated just in between two SCIAMACHY orbits, and only slightly enhanced amounts are seen at the edges of the plume in the adjacent orbits (at $50^{\circ} \mathrm{N}, 210^{\circ} \mathrm{E}$, and $55^{\circ} \mathrm{N}, 225^{\circ} \mathrm{E}$ ), the SCIAMACHY IO column amounts are largest on day 11 August. Slant columns reach up to $4.9 \times 10^{13}$ molec $\mathrm{cm}^{-2}$ for IO and $5.6 \times 10^{14}$ molec $\mathrm{cm}^{-2}$ for BrO. These values correspond to vertical columns of $2.1 \times 10^{13} \mathrm{molec} \mathrm{cm}^{-2}$ for IO and $2.5 \times 10^{14} \mathrm{molec} \mathrm{cm}^{-2}$ for BrO. While these large column amounts of $\mathrm{BrO}$ from volcanic emission have been reported before (Theys et al., 2009), IO produced by volcanic activity is observed for the first time.

The IO column amounts in the Kasatochi emission plume are larger than the upper limit for IO slant columns of 7.6 to $8.6 \times 10^{12}$ molec cm$^{-2}$ reported by Gliß et al. (2015) for the degassing of Mt Etna in September 2012. These results are not in contradiction with the satellite observations in the present study, as different volcanos show individual gas-phase compositions, and degassing phases may differ strongly from eruptive periods.

\subsection{IO detection with GOME-2A}

Maps of IO retrieved from GOME-2A data for the 6 days after the eruption are shown in Fig. 2 (middle), next to the SCIAMACHY results for direct comparison. $\mathrm{BrO}$ amounts retrieved from GOME-2A are shown in the right column. Due to the much better spatial coverage of the GOME-2A instrument as compared to the SCIAMACHY instrument, the IO plume from the volcanic emission is clearly visible on all 6 days. The spatial shape of the IO enhancement agrees well with the area where higher $\mathrm{BrO}$ is observed.

As a comparison of the IO results retrieved from the two different sensors, an example collocation case from $11 \mathrm{Au}-$ gust 2008 has been chosen. The comparison includes the IO from the SCIAMACHY retrieval as well as IO from both GOME-2A retrievals, and the results are summarized in Table 2. The IO retrieval settings are discussed in Sect. 2.2, and the corresponding spectral fits are shown in Fig. 3.
The IO results of the three retrievals are consistent within their uncertainties. The GOME-2A spectral retrievals are of good quality, with relative fitting errors of around $14 \%$. The fitting error is thus larger than for the SCIAMACHY retrieval. The IO detection limit for GOME-2A observations is on the order of $5 \times 10^{12}$ molec cm $\mathrm{cm}^{-2}$ in terms of vertical columns and around $1 \times 10^{13}$ molec $\mathrm{cm}^{-2}$ for the retrieved slant columns, depending on several factors, such as the received radiance and solar zenith angle. For the discussed examples, the GOME-2A instrument detects slightly less IO than the SCIAMACHY instrument. On other collocation events the relation is, however, reversed. The ground scenes of the two instruments are not identical, and the measurement times typically differ by half an hour. For rapidly moving volcanic plumes, differences in the detected IO column amounts by the two instruments are expected, either as result of changing IO concentrations due to relatively fast and complex multiphase photochemical reactions, the size of the ground scene, or changing ground or cloud albedo.

\subsection{Analysis of $\mathrm{IO}$ and $\mathrm{BrO}$ amounts}

The spatial sampling of spectra by the GOME-2A instrument is intrinsically better than that of the SCIAMACHY instrument, and the full volcanic plume is observed on several days. Consequently, GOME-2A IO results provide a more accurate analysis and representation of the total iodine amount and mass emitted from the Kasatochi eruption than the IO results retrieved from SCIAMACHY. Integration over the IO amount inside the plume is performed. For this purpose, the plume itself needs to be defined first. Here, the plume is defined as the area enclosing those satellite pixels with an IO column amount above a certain threshold. This threshold is defined as $\mathrm{VC}_{\mathrm{IO}, \text { thr }}=\left\langle\mathrm{VC}_{\mathrm{IO}}\right\rangle+2 \sigma_{\mathrm{IO}}$, where $\left\langle V C_{\mathrm{IO}}\right\rangle$ is the mean IO vertical column and $\sigma_{\mathrm{IO}}$ is its standard deviation. Both parameters are derived from measurements on the days before the eruption as explained below. For $\mathrm{BrO}$, the procedure is almost the same, but the threshold is set at $3 \sigma_{\mathrm{BrO} O}$ above the mean. For IO, the weaker criterion of $2 \sigma$ is necessary in order to capture the plume well. The reason for this is the larger noise as compared to that of the $\mathrm{BrO}$ data, i.e. enhanced IO amounts are closer to the detection limit than is the case for $\mathrm{BrO}$. Mean and standard deviation values for $\mathrm{IO}$ and $\mathrm{BrO}$ are calculated using the data from 3 consecutive days of satellite coverage prior to the eruption (5 to 7 August 2008) and from within a wide area around the volcano $\left(40-62.5^{\circ} \mathrm{N}, 183.5-231^{\circ} \mathrm{E}\right)$ enclosing all main plumes on the following days. Threshold values are $5.3 \times 10^{12}$ and $9.7 \times 10^{13}$ molec cm $^{-2}$ for IO and BrO, respectively. Only a small background IO slant column is found prior to the eruption (around $0.4 \times 10^{12}$ molec $\mathrm{cm}^{-2}$ and below the detection limit), while the $\mathrm{BrO}$ column has a substantial stratospheric as well as free-tropospheric contribution of around $6.1 \times 10^{13}$ molec cm $^{-2}$ in this area. 
Table 2. IO retrieval results from the collocation case between SCIAMACHY and GOME-2A on 11 August 2008. The three results agree within their fitting errors.

\begin{tabular}{|c|c|c|c|}
\hline Retrieval results & SCIAMACHY & GOME-2A $2 \mathrm{~T}$ & GOME-2A $3 \mathrm{~T}$ \\
\hline Fitting window & $416-430 \mathrm{~nm}$ & $416-430 \mathrm{~nm}$ & $418-438 \mathrm{~nm}$ \\
\hline $\mathrm{SC}_{\mathrm{IO}} / 10^{13}$ molec $\mathrm{cm}^{-2}$ & $4.58 \pm 0.28$ & $4.25 \pm 0.60$ & $4.14 \pm 0.59$ \\
\hline
\end{tabular}

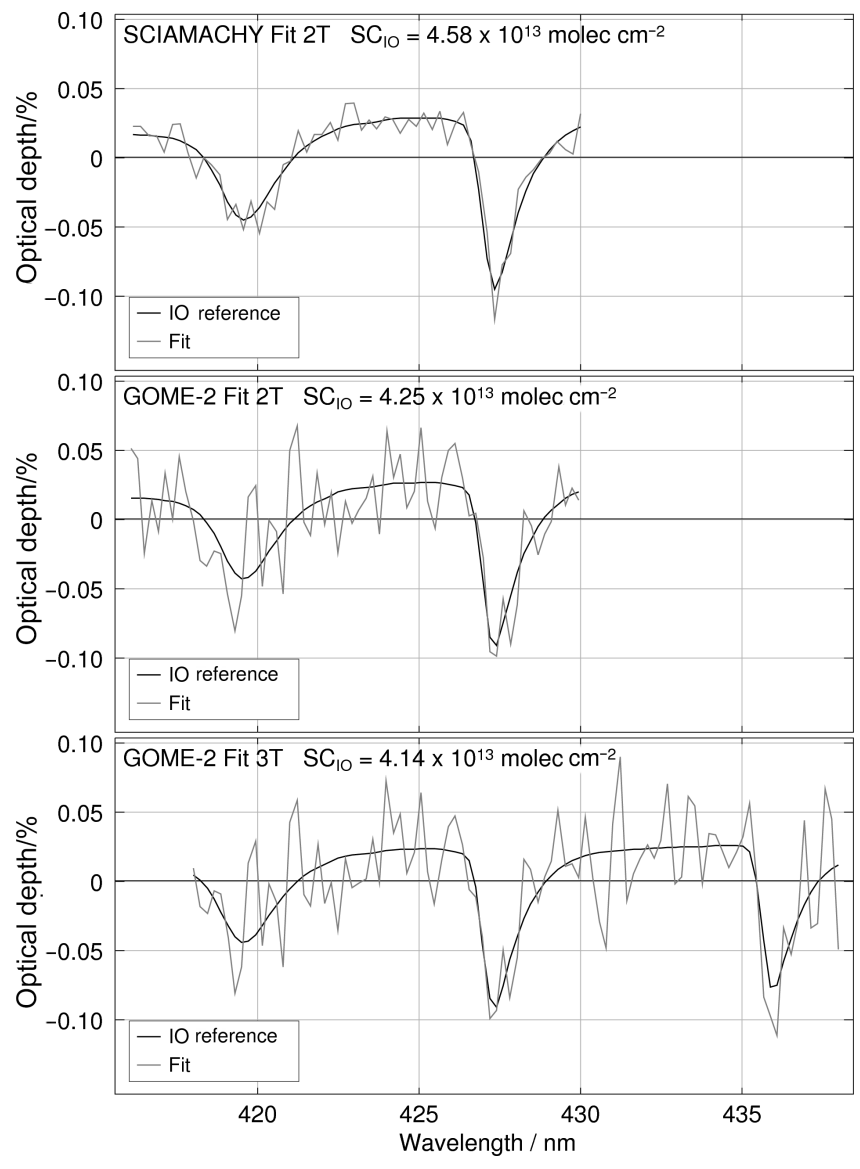

Figure 3. Spectral fitting results from day 11 August 2008 for a collocation between SCIAMACHY (top) and GOME-2A around $55^{\circ} \mathrm{N}$ and $220^{\circ} \mathrm{E}$. For GOME-2A, the results from two different fitting windows are shown, using the SCIAMACHY standard IO fitting window (centre) and using a larger spectral window covering three spectral absorption bands of IO (bottom).

In an alternative approach, the observed $\mathrm{SO}_{2}$ column amount (cf. Sect. 3.4) is used in order to select the $\mathrm{BrO}$ and $\mathrm{IO}$ in the volcanic plume. For this $\mathrm{SO}_{2}$ mask approach, the plume is defined by applying a $10 \mathrm{DU}$ limit to the $\mathrm{SO}_{2}$ distribution. Following the plume definition and background subtraction, the $\mathrm{IO}$ and $\mathrm{BrO}$ column amounts are integrated over the selected plume area. This yields an integrated number of molecules originating from the volcanic eruption. For the days 8 to 12 August 2008, the results of this procedure are shown as a time series for $\mathrm{IO}$ and $\mathrm{BrO}$ in Fig. 4. Results from

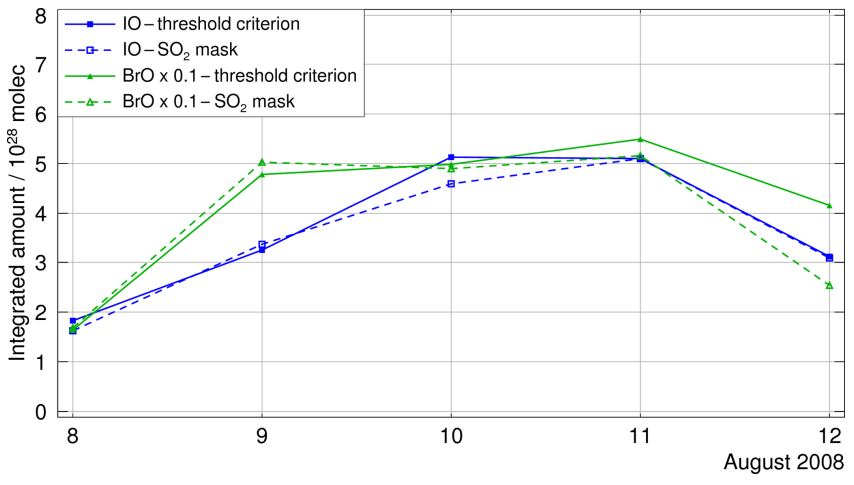

Figure 4. Time series of integrated $\mathrm{IO}$ (blue) and $\mathrm{BrO}$ (green) amounts. BrO data is scaled by a factor of 0.1. For both trace gases, two methods for the plume definition are applied, the threshold criterion and the $\mathrm{SO}_{2}$ mask.

the threshold criterion are displayed and compared to those obtained using the $\mathrm{SO}_{2}$ mask approach.

On days 8 to 11 August 2008, the two methods agree within a few percent, while the actual plume shape differs slightly at the edges. On 12 August 2008, the difference of the plume positions between $\mathrm{SO}_{2}$ on one hand and $\mathrm{BrO}$ and IO on the other is larger. For IO, the difference does not affect the integrated value much, while for $\mathrm{BrO}$, the results from the two different selection routines differ by $60 \%$. Using the $\mathrm{SO}_{2}$ mask, part of the BrO plume is missed. For IO, the values in that region are lower. Consequently, the influence of the precise plume shape on the calculation of the integrated amount is less pronounced. In general, the two methods are in agreement but, due to the latter finding, the method using the $\sigma$-level criterion is preferred.

On day 8 August, just after the start of the eruption, approximately $1.8 \times 10^{28}$ molecules of IO are observed in the plume, corresponding to a mass of $4.3 \mathrm{Mg}$ or metric tons, $\mathrm{t}$, of IO. The amount of IO increases to $7.7 \mathrm{t}$ on 9 August, reaches up to 12.2 and $12.1 \mathrm{t}$ (i.e. around $5.1 \times 10^{28}$ molecules of $\mathrm{IO}$ ) on the peak days 10 and 11 August, respectively, and decreases back to $7.4 \mathrm{t}$ on 12 August. The integrated mass of IO hence ranges between 4.3 and $12.2 \mathrm{t}$. Using the molar masses of iodine and oxygen, this amount of IO contains an integrated mass of reactive iodine between 3.9 and $10.8 \mathrm{t}$.

The integrated mass of $\mathrm{BrO}$ within the plume increases from $26 \mathrm{t}$ on 8 August to $76 \mathrm{t}$ and $79 \mathrm{t}$ on 9 and 10 August and reaches a maximum of $87 \mathrm{t}$ on 11 August. On 12 August 
2008, an integrated mass of $66 \mathrm{t}$ of $\mathrm{BrO}$ remains in the volcanic plume. Directly converting the integrated mass of $\mathrm{BrO}$ between 26 and $87 \mathrm{t}$ to the corresponding integrated mass of reactive $\mathrm{Br}$, a range between 22 and $73 \mathrm{t}$ is derived using the molar masses of bromine and oxygen. These integrated $\mathrm{BrO}$ amounts are larger but in broad agreement with calculations by Theys et al. (2009), who use the FLEXPART dispersion model and derive the total amount of $\mathrm{BrO}$ within the volcanic plume to be around 30 to $42 \mathrm{t}$. In addition to $\mathrm{BrO}$, other bromine compounds contribute to the total bromine mass. In the relevant altitude between 8 and $12 \mathrm{~km}, 30-50 \%$ of the total inorganic bromine exist in the form of $\mathrm{BrO}$ (Theys et al., 2009). Using this relation, the integrated $\mathrm{BrO}$ amount corresponds to a total mass of 50 to $290 \mathrm{t}$ of reactive bromine.

Although knowledge on iodine chemistry in a volcanic plume is limited, other iodine compounds such as $\mathrm{I}_{2}, \mathrm{I}, \mathrm{HI}$, $\mathrm{HOI}, \mathrm{OIO}$ and higher iodine oxides are presumably present in the emission plume as well. Consequently, the emitted mass of iodine (3.9 to $10.8 \mathrm{t}$ ) can be regarded as a lower limit for the iodine content in the Kasatochi emission plume because this range is derived directly from the IO observations. Detailed chemical modelling would be needed to derive the total amount of reactive iodine in the volcanic plume from the observed IO column amounts by taking into account the other iodine species and all known chemical reactions that are taking place in the hot exhaust of the individual volcano. Such a modelling exercise is, however, out of the scope of the current study. In addition to the presence of other iodine species, iodine oxides may polymerize into particles, while there is no evidence that bromine oxides do under atmospheric conditions. This might lead to an underestimation of the iodine to bromine ratio if only gas-phase species are considered.

The emitted mass of iodine inferred for the Kasatochi eruption in August 2008 is of the same order of magnitude as previously determined for the annually integrated flux for degassing volcanos, e.g. $10 \mathrm{tyr}^{-1}$ of iodine at Mt Etna, Italy, (Aiuppa et al., 2005) or $12 \mathrm{t} \mathrm{yr}^{-1}$ at Satsuma-Iwojima, Japan (Snyder and Fehn, 2002). This is in line with observations for bromine, where for one given volcano the Br flux from an individual eruption can be of the same order of magnitude as the annual Br flux from degassing (Aiuppa et al., 2005). The temporal evolution of the integrated amounts is discussed in Sect. 4.

\subsection{Spatial distributions of $\mathrm{IO}, \mathrm{BrO}$ and $\mathrm{SO}_{2}$}

In order to investigate the spatial plume structure more closely, Fig. 5 gives an expanded view of the volcanic plume. The retrieved column amounts of IO (left) and $\mathrm{BrO}$ (centre) are shown together with those of $\mathrm{SO}_{2}$ (right) for the days 9 August 2008 (top) and 11 August 2008 (bottom). $\mathrm{SO}_{2}$ column amounts are derived in the spectral window between 312.5 and $327 \mathrm{~nm}$ using an iterative retrieval approach (Richter, 2009).
Previous satellite studies reported that $\mathrm{BrO}$ is often enhanced around the plume centre (Hörmann et al., 2013). For the two depicted cases, the IO column amount is also lower in the plume centre than in some areas around the centre. In general, the $\mathrm{IO}$ and $\mathrm{BrO}$ plumes have a similar spatial extent and shape. It is however interesting to note, that maximum $\mathrm{IO}$ and $\mathrm{BrO}$ column amounts are not observed in the same satellite pixels and that the details of the spatial patterns differ. On 9 August 2008, the largest $\mathrm{BrO}$ enhancements are detected in the west and east of the plume, while IO is also enhanced there but even more so in the south of the plume. On 11 August 2008, BrO maxima are seen in the west, and IO maxima are split into two regions in the north and south of the volcanic plume.

The IO and $\mathrm{BrO}$ vertical column amounts that are observed within a rectangular latitude-longitude box which encloses the entire volcanic plume are investigated for each individual day between 8 and 12 August 2008. The correlation coefficient between $\mathrm{IO}$ and $\mathrm{BrO}$ considering the data from the respective area lies between $R=0.62$ and $R=0.84$ on the days from 9 to 12 August 2008. On the first day, 8 August, the correlation is lower, at $R=0.42$. These results with relatively large and positive values of $R$ indicate that iodine and bromine compounds are emitted together into the volcanic plume but also that there are factors influencing the temporal evolution of the two gases differently as $R$ is clearly below unity $(R<0.85)$.

The $\mathrm{IO}$ and $\mathrm{BrO}$ distributions are again similar to those of $\mathrm{SO}_{2}$, but even larger differences occur than between the distributions of the two halogen compounds. For $\mathrm{SO}_{2}$, no occurrence of lower values in the plume centre is observed. On some days, such as the example day 11 August, $\mathrm{SO}_{2}$ is at maximum in the plume centre. On day 9 August, two $\mathrm{SO}_{2}$ maxima are seen, with one part crossing the plume centre and one part situated more to the southern edge of the plume. The three different trace gases observed by satellite hence show several individual aspects in their spatial distribution within the volcanic plume.

\section{Discussion}

When comparing the integrated numbers of $\mathrm{IO}$ and $\mathrm{BrO}$ molecules in the volcanic plume, one important and interesting point is that the amount of iodine is only about 1 order of magnitude smaller than that of bromine. For the individual days from 9 to 12 August 2008, the ratio for the integrated number of $\mathrm{BrO}$ to $\mathrm{IO}$ molecules lies between 6.7 and 10.0 and amounts to 4.2 on 8 August 2008. The corresponding mass ratio for $\mathrm{BrO}$ to $\mathrm{IO}$ ranges between 4.0 and 6.7 and amounts to 2.8 on 8 August 2008, using data from Fig. 4 .

Figure 6 shows a scatterplot between IO and $\mathrm{BrO}$ column amounts from the individual satellite observations. Data from the 4-day period, 9 to 12 August 2008, is included in the comparison. As in the correlation analysis described in Sect. 3.4, 

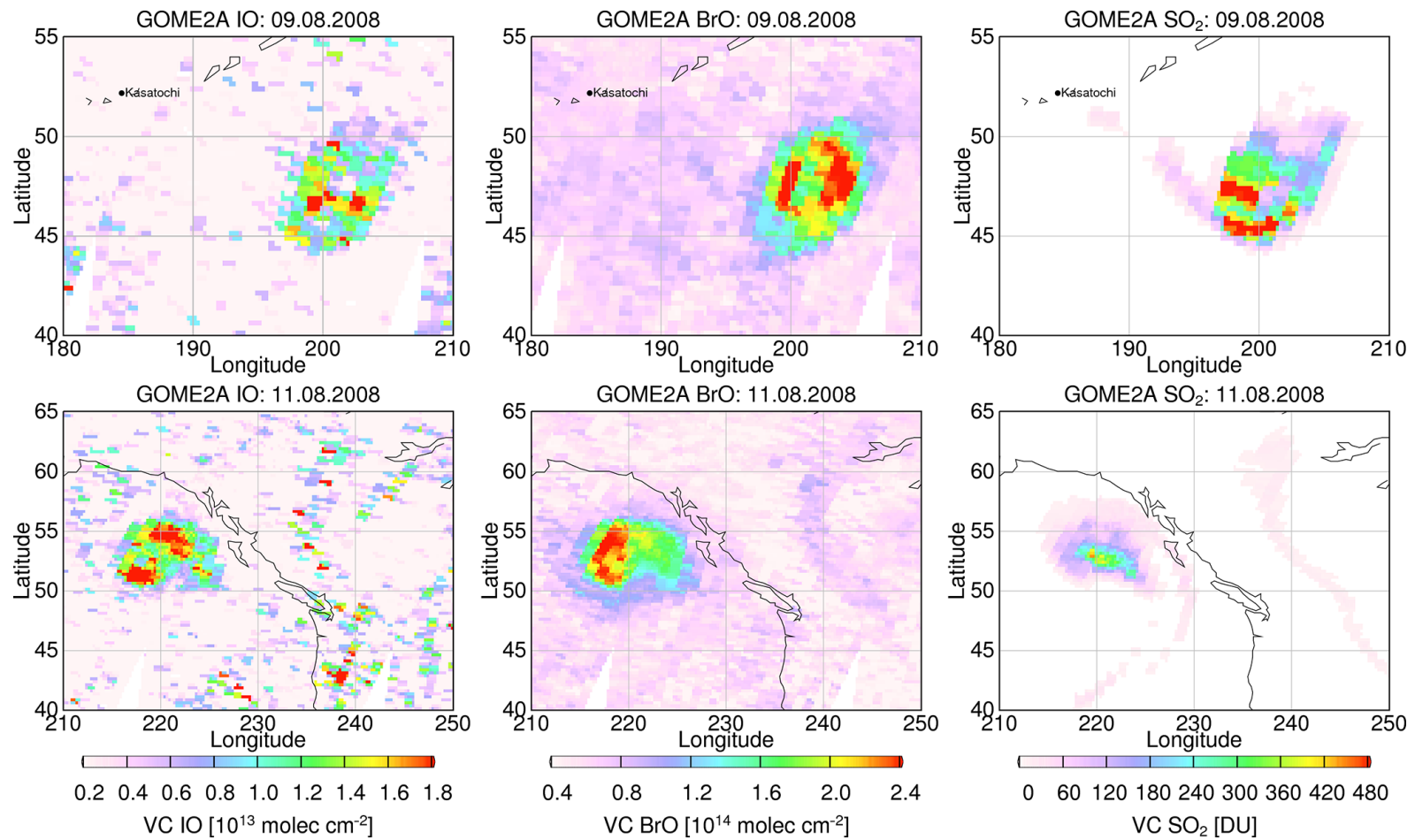

Figure 5. Close-up of the volcanic plumes of $\mathrm{IO}$ (left), $\mathrm{BrO}$ (centre) and $\mathrm{SO}_{2}$ (right) on the days 9 August (top) and 11 August (bottom), 2008. While the plume extent and shape are similar, differences in the spatial distribution patterns are visible.

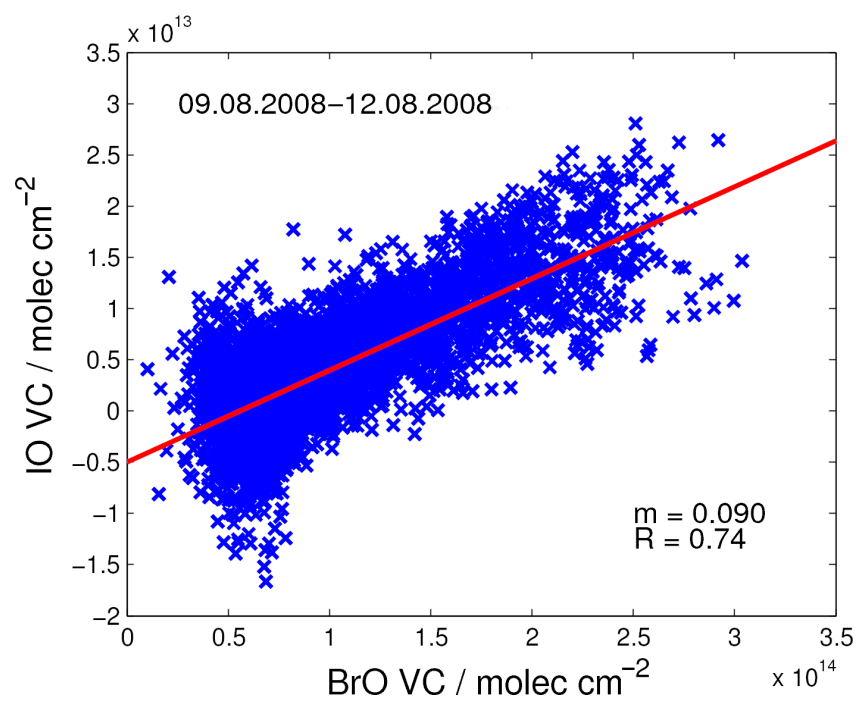

Figure 6. Scatterplot of IO vs. BrO column amounts. Data from the 4 days from 9 to 12 August 2008 is included.

for each day those measurements that fall into a rectangular area enclosing the volcanic plume are used. The slope for all data of $\mathrm{IO}$ vs. $\mathrm{BrO}$ columns is 0.09 , with a correlation coefficient of 0.74 . This observation is consistent with findings by Aiuppa et al. (2009), who estimate a 1 order of magnitude difference between the volcanic abundances of the two halogen species iodine and bromine. In addition, Pyle and Mather (2009) estimate the annual fluxes of volcanic $\mathrm{HBr}$ and $\mathrm{HI}$ to be on the order of $5-15 \mathrm{Gg} \mathrm{yr}^{-1}$ for $\mathrm{HBr}$ and $0.5-$ $2 \mathrm{Gg} \mathrm{yr}^{-1}$ for $\mathrm{HI}$, respectively. The uncertainties in emission fluxes given by the latter study are rather large, but the results for the halogen flux ratios agree with the present satellite observations within their error bars.

The interesting point is that the seawater abundance yields a ratio of $\mathrm{Br} / \mathrm{I}$ of 15000 , i.e. a 4 order of magnitude difference between I and $\mathrm{Br}$. By considering singly the $\mathrm{IO}$ and $\mathrm{BrO}$ observations, the number ratio between iodine and bromine atoms is thus enhanced by about 3 orders of magnitude in the volcanic plume as compared to seawater. Modelling of the halogen chemistry within the volcanic plume would be required to calculate the iodine and bromine amounts from the $\mathrm{IO}$ and $\mathrm{BrO}$ column observations. These estimates are performed under the given restrictions, and the present observations of volcanic emissions of IO shall encourage including the chemistry of iodine and iodine oxides in volcanic halogen chemistry modelling in the future. Other studies have shown that while the $\mathrm{Cl}$ vs. $\mathrm{Br}$ ratio for volcanic condensates is in agreement with the seawater ratio of around 650 (Gerlach, 2004; Aiuppa et al., 2005), the ratio of $\mathrm{Cl}$ vs. I is about 2 orders of magnitude lower in volcanic plumes than in seawater (Honda et al., 1966; Honda, 1970; Snyder and Fehn, 2002; Aiuppa et al., 2005). Consequently, an enhancement of io- 
dine species takes place in the processes which determine the release of halogens from volcanic activity.

Explanations for the observed enhancement of iodine in volcanic emissions relative to seawater are connected to the magma composition of the specific volcano. As Kasatochi is an oceanic arc volcano, marine sediments which are carried into the Earth mantle at the subduction zone directly influence the composition of the volcanic material. Marine sediments in turn are enriched in iodine compounds from organic material (Muramatsu and Wedepohl, 1998). In addition, volcanic emissions are influenced by the composition of the melts and fluids in the volcanic chamber. Results of hydrothermal experiments were used to analyse the compositions of hydrous fluids and silicate melts with respect to the different halogens (Bureau et al., 2000). It was found that the partition coefficient between fluid and melt is clearly larger for iodine than for bromine and chlorine. The partitioning into the fluid phase is therefore stronger for iodine than for bromine, which is again stronger than for chlorine. Consequently, volcanic emissions to the atmosphere are expected to be enhanced in iodine relative to the other halogens.

It is also of interest to study the temporal evolution of the observed IO and $\mathrm{BrO}$ column amounts within the plume. The observations on the first day after the eruption, however, may be influenced by dust and clouds accompanying the eruption, especially close to the volcano (Theys et al., 2009). Consequently, trace gas amounts could be larger than quantified by the spectroscopic observations. Comparison of the temporal behaviour of $\mathrm{IO}$ and $\mathrm{BrO}$ shows that their evolution is similar, with maximum integral amounts detected 1 to 3 days after the eruption (cf. Fig. 4). BrO reaches its highest values (around $5 \times 10^{29}$ molecules) earlier than IO. The different chemical pathways and time constants for $\mathrm{IO}$ and $\mathrm{BrO}$ production and destruction also influence the temporal variation of the I / Br ratio. However, the temporal changes between 9 and 12 August 2008 are close to the limit of being significant. Considering only the $1 \sigma$ standard deviation of IO on the order of $2.5 \times 10^{12}$ molec $\mathrm{cm}^{-2}$, the uncertainty on the integrated IO molecule number within the volcanic plume lies between 0.8 and $1.2 \times 10^{28}$, using the plume areas from 9 and 11 August, respectively. As a result, details in the temporal evolution need to be interpreted with care. Overall, it is interesting to note that the ratio of observed $\mathrm{IO}$ and $\mathrm{BrO}$ (Fig. 4) shows little change during the aging of the plume within the 5 analysed days. This observation may imply that higher iodine oxides, which are formed more rapidly at larger IO concentrations (cf. estimation of IO mixing ratios below), are photochemically labile inside the volcanic plume. Thereby, the IO may persist in the plume for a longer time period than what would be expected from the atmospheric lifetime of IO. The evolution of iodine species in the volcanic plume may be further affected by particle formation and heterogeneous reactions. Murphy and Thomson (2000) measured enhanced iodine content in aerosols in the upper troposphere and lower stratosphere (UTLS) region. This finding has two further im- plications. Particles may serve as a sink for iodine, reducing the availability of reactive iodine, and, on the other hand, they may provide pathways for heterogeneous reactions from which reactive iodine compounds may be released again.

The spatial distributions of $\mathrm{IO}, \mathrm{BrO}$ and $\mathrm{SO}_{2}$ are described in Sect. 3.4, and some differences between the three species are observed. The chemical pathways of iodine and bromine within the plume are probably not independent from each other. Formation and loss processes may interfere with each other. Although the rate coefficients for the reactions of I and $\mathrm{Br}$ with $\mathrm{O}_{3}$ are similar, the smaller expected concentrations of I than $\mathrm{Br}$ imply that the time constant for IO production is larger than that for $\mathrm{BrO}$. As a consequence, large amounts of $\mathrm{Br}$ that react with $\mathrm{O}_{3}$, thereby strongly reducing the $\mathrm{O}_{3}$ abundance, may prevent the build-up of IO. This results in spatially separated maximum values for the two halogen oxides. The reactions between $\mathrm{IO}$ and $\mathrm{BrO}$, as well as self reactions of IO, also impact the spatial distributions and maximum amounts. Furthermore, the time of emission of the precursor substances may differ to some degree. Iodine and bromine have different solubility in volcanic fluids (Aiuppa et al., 2009). For the two halogen species, degassing from the magma may therefore take place at different pressures, i.e. at different depth of the volcanic abyss. In addition, some clear differences between the spatial distributions of the halogen oxides and $\mathrm{SO}_{2}$ are found. In general, the comparison between the trace gas spatial distributions is interesting because it potentially yields information on the eruption process and chronology. Details of the plume composition and evolution need to be analysed in the future by chemical transport modelling to provide better insight into the complex reactions taking place within the plume.

For an estimate of the impact of volcanic iodine on atmospheric chemistry, the volume mixing ratio is a more relevant quantity than the column amount. For a rough estimate, the vertical plume extent derived by Theys et al. (2009) is used. They determine the major part of the plume to reside between 8 and $12 \mathrm{~km}$ altitude. The retrieved integrated number of IO molecules of about $5 \times 10^{28}$ molecules, for 10 and 11 August 2008 , is used as lower limit of the emitted iodine amount. On both days, the plume extends horizontally over $5 \times 10^{5} \mathrm{~km}^{2}$. Spreading the observed IO homogeneously within the $4 \mathrm{~km}$ thick layer and over the entire plume extent, the average VMR would be around 3 pptv at $10 \mathrm{~km}$ altitude using US standard atmosphere pressure and temperature values. Certainly, local VMR values will exceed this average VMR due to an inhomogeneous distribution within the plume. Iodine mixing ratios of 3 pptv may have a strong impact on ozone concentrations (Bösch et al., 2003; Saiz-Lopez et al., 2015a) and constitute a large perturbation of stratospheric iodine, which is measured and estimated to be on the sub-pptv level.

Iodine from volcanic eruptions has several possible implications for atmospheric composition. The upper part of the Kasatochi plume may have reached into the lower stratosphere. Consequently, the presented satellite-based observa- 
tions of iodine monoxide indicate that volcanic eruptions may have an impact on the iodine concentrations in the upper troposphere and lower stratosphere, at least regionally.

The above estimated IO VMR of 3 pptv in the Kasatochi plume will be diluted with time. Spreading the released trace gas amount over the area of the entire globe decreases the VMR at the given altitude by 3 orders of magnitude as compared to the plume area. Consequently, strong implications for ozone depletion through iodine from a single volcanic eruption are probably mainly regional and restricted in time. Primarily, the lower stratosphere or UTLS region is affected. However, the region impacted by the emitted iodine may be dislocated from the erupting volcano due to the quickly moving volcanic plume covering distances of typically around several hundred $\mathrm{km}$ per day.

Due to the larger chain length for the removal of $\mathrm{O}_{3}$ by $\mathrm{BrO}_{x}$ and $\mathrm{IO}_{x}$ than by $\mathrm{ClO}_{x}$, loss of $\mathrm{O}_{3}$ in the stratosphere can be significantly impacted by the $\mathrm{BrO}$ and $\mathrm{IO}$ in addition to $\mathrm{ClO}$ released from volcanic eruptions. In this case the lower stratosphere may become most affected. This could impact on ozone hole chemistry when volcanic eruptions enter the polar vortices, an issue recently raised by Solomon et al. (2016).

Background iodine amounts between 0.1 and 0.4 pptv in the free troposphere as observed recently (Puentedura et al., 2012; Dix et al., 2013) are possibly also influenced by volcanic activity. Following a volcanic eruption, the iodine amount will directly influence the local and regional chemistry by reducing the ozone levels. The impact of the ability of volcanic IO to form aerosol condensation nuclei requires further study. In addition, volcanic plumes may be subject to long-range transport and therefore lead to effects also at larger distances.

The Kasatochi eruption was in some respect special as it was a major eruption; the plume altitude was relatively large and bromine amounts were also larger than for other investigated volcanic plumes (Hörmann et al., 2013). IO has not yet been detected for any other eruptions investigated, at least not at the Kasatochi levels. Scaling with the observed bromine amounts, iodine levels for the other eruptions could just be below or around the detection limit of current space-based instruments. Future satellite instruments with finer spatial resolution and improved signal-to-noise ratio may allow the observation and detailed investigation of iodine species in volcanic plumes more frequently.

It is interesting to speculate on the amount of halogens emitted to the atmosphere from past major eruptions which have severely impacted atmospheric composition prior to halogen observations from space. For the Pinatubo eruption in 1991, for example, a total mass of about $20 \mathrm{Tg}$ of $\mathrm{SO}_{2}$ was emitted. The eruption injected gases and aerosols up to 25$30 \mathrm{~km}$ altitude, i.e. around the maximum stratospheric ozone mixing ratio. In relative terms, the IO VMR will be increased at these high altitudes due to much lower air density as compared to the Kasatochi estimates. Assuming a similar magma composition as that of Kasatochi, i.e. similar halogen to sulfur ratios, an amount of around $100 \mathrm{t}$ of IO as well as $1 \mathrm{kt}$ of $\mathrm{BrO}$ could have been emitted into the stratosphere from Pinatubo, with corresponding impact on stratospheric chemistry over extended horizontal distances and periods. A detailed assessment again requires better knowledge and studies of the loss of iodine and bromine into the stratospheric aerosol.

\section{Summary and conclusions}

Following the major eruption of the Kasatochi volcano in August 2008, iodine monoxide is observed by satellite in the volcanic plume for several days. This is the first experimental evidence of IO emitted from a volcanic eruption. The satellite sensors SCIAMACHY and GOME-2A both detect slant column amounts of IO above $4 \times 10^{13}$ molec $\mathrm{cm}^{-2}$ in the volcanic plume for several days following the Kasatochi eruption. Maximum vertical columns above $2 \times 10^{13}$ molec cm $^{-2}$ are derived. The presented observations also represent the first reported retrievals of $\mathrm{IO}$ from measurements of the GOME-2A instrument. In comparison to tropospheric IO observations in polar and mid-latitudinal regions, the observed column amounts are large, reducing the uncertainties and facilitating analysis of individual measurements. The IO data in the plume shows good fitting quality with fitting errors around $6 \%$ for SCIAMACHY and below $15 \%$ for GOME$2 \mathrm{~A}$ retrievals.

Overall, the IO enhancements coincide in space with previously published observations of $\mathrm{BrO}$ and $\mathrm{SO}_{2}$. While the plumes of $\mathrm{IO}, \mathrm{BrO}$ and $\mathrm{SO}_{2}$ are roughly found in the same area with similar shape, the maximum amounts of the individual species, however, do not always coincide. Differences between $\mathrm{IO}$ and $\mathrm{BrO}$ are smaller than those between the halogens and $\mathrm{SO}_{2}$. The emission chronology as well as chemical conversions are presumably individual for the three compounds and could probably lead to the observed differences in spatial distributions.

Correlating all observations of $\mathrm{IO}$ and $\mathrm{BrO}$ between 9 to 12 August 2008 yields a slope of 0.09 , i.e. IO amounts are about 1 order of magnitude smaller than those of BrO. Judging from the $\mathrm{IO}$ and $\mathrm{BrO}$ column amounts alone, this volcanic ratio indicates a 3 order of magnitude difference with respect to the seawater ratio between iodine and bromine, in agreement with previous filter measurements of volcanic samples at arc volcanos. For this relative enhancement of iodine, two reasons play a role. Iodine shows a stronger preference than bromine for partitioning into volcanic fluid than melt in the volcanic chamber located underneath the volcano. This relative partitioning between fluid and melt determines the gasphase composition of an eruption plume. In addition, iodineenriched marine sediments are carried into the Earth's mantle in the subduction zone and directly influence the composition of the magma. 
An integration of the observed IO amount within the emission plume results in a large mass of around $10 t$ ( 4 to $12 t)$ of $\mathrm{IO}$ emitted from the volcano. By comparing the integrated numbers of $\mathrm{IO}$ and $\mathrm{BrO}$ molecules found within the volcanic plume, the $\mathrm{BrO} / \mathrm{IO}$ number ratio ranges between 6.7 and 10.0, while the $\mathrm{BrO} / \mathrm{IO}$ mass ratio lies between 4.0 and 6.7. Together with the knowledge that the Kasatochi BrO plume predominantly reached the altitude between 8 and $12 \mathrm{~km}$, it can be concluded that a substantial input of iodine to the lower stratosphere, UTLS and free troposphere has taken place following the Kasatochi eruption. If the IO amount is homogeneously spread over the plume area and within the main $4 \mathrm{~km}$ thick vertical layer, a VMR of 3 pptv at an altitude of $10 \mathrm{~km}$ results. The local VMR can be even higher due to inhomogeneous distribution in the volcanic plume. Iodine volume mixing ratios of around 3 pptv may have substantial impact on atmospheric composition, e.g. through regionally reducing the ozone concentrations.

The investigation of past and future volcanic eruptions with respect to their IO content and impact on tropospheric and stratospheric chemistry is subject to further work and will be facilitated by improved satellite instrumentation in the future.

Data availability. Satellite trace gas column data from SCIAMACHY and GOME-2A observations can be obtained from the authors upon request.

Competing interests. The authors declare that they have no conflict of interest.

Acknowledgements. SCIAMACHY level 1 data have been provided by ESA (European Space Agency) and DLR (Deutsches Zentrum für Luft- und Raumfahrt), and GOME-2A level 1 data have been provided by EUMETSAT. Financial support through the University of Bremen Institutional Strategy Measure M8 in the framework of the DFG Excellence Initiative is gratefully acknowledged for AS. This study is in part a contribution to the DFG SFB TR 172.

The article processing charges for this open-access publication were covered by the University of Bremen.

Edited by: M. Chipperfield

Reviewed by: two anonymous referees

\section{References}

Aiuppa, A., Federico, C., Franco, A., Giudice, G., Gurrieri, S., Inguaggiato, S., Liuzzo, M., McGonigle, A. J. S., and Valenza, M.: Emission of bromine and iodine from Mount Etna volcano, Geochem. Geophy. Geosy., 6, Q08008, doi:10.1029/2005GC000965, 2005.

Aiuppa, A., Baker, D., and Webster, J.: Halogens in volcanic systems, Chem. Geol., 263, 1-18, doi:10.1016/j.chemgeo.2008.10.005, 2009.

Alicke, B., Hebestreit, K., Stutz, J., and Platt, U.: Iodine oxide in the marine boundary layer, Nature, 397, 572-573, 1999.

Begoin, M., Richter, A., Weber, M., Kaleschke, L., Tian-Kunze, X., Stohl, A., Theys, N., and Burrows, J. P.: Satellite observations of long range transport of a large BrO plume in the Arctic, Atmos. Chem. Phys., 10, 6515-6526, doi:10.5194/acp-10-65152010, 2010.

Bobrowski, N. and Platt, U.: $\mathrm{SO}_{2} / \mathrm{BrO}$ ratios studied in five volcanic plumes, J. Volcanol. Geoth. Res., 166, 147-160, doi:10.1016/j.jvolgeores.2007.07.003, 2007.

Bobrowski, N., Hönninger, G., Galle, B., and Platt, U.: Detection of bromine monoxide in a volcanic plume, Nature, 423, 273-276, 2003.

Bobrowski, N., Hönninger, G., Lohberger, F., and U., P.: IDOAS: A new monitoring technique to study the $2 \mathrm{D}$ distribution of volcanic gas emissions, J. Volcanol. Geoth. Res., 150, 329-338, doi:10.1016/j.jvolgeores.2005.05.004, 2006.

Bobrowski, N., von Glasow, R., Aiuppa, A., Inguaggiato, S., Louban, I., Ibrahim, O. W., and Platt, U.: Reactive halogen chemistry in volcanic plumes, J. Geophys. Res.-Atmos., 112, D06311, doi:10.1029/2006JD007206, 2007.

Bogumil, K., Orphal, J., Homann, T., Voigt, S., Spietz, P., Fleischmann, O. C., Vogel, A., Hartmann, M., Bovensmann, H., Frerik, J., and Burrows, J. P.: Measurements of Molecular Absorption Spectra with the SCIAMACHY Pre-Flight Model: Instrument Characterization and Reference Data for Atmospheric Remote-Sensing in the 230-2380 nm Region, J. Photochem. Photobiol. A, 157, 167-184, 2003.

Bösch, H., Camy-Peyret, C., Chipperfield, M. P., Fitzenberger, R., Harder, H., Platt, U., and Pfeilsticker, K.: Upper limits of stratospheric IO and OIO inferred from center-to-limb-darkeningcorrected balloon-borne solar occultation visible spectra: Implications for total gaseous iodine and stratospheric ozone, J. Geophys. Res., 108, 4455, doi:10.1029/2002JD003078, 2003.

Bovensmann, H., Burrows, J. P., Buchwitz, M., Frerick, J., Noël, S., Rozanov, V. V., Chance, K. V., and Goede, A. P. H.: SCIAMACHY: Mission Objectives and Measurement Modes, J. Atmos. Sci., 56, 127-150, 1999.

Bureau, H., Keppler, H., and Métrich, N.: Volcanic degassing of bromine and iodine: experimental fluid/melt partitioning data and applications to stratospheric chemistry, Earth Planet. Sci. Lett., 183, 51-60, 2000.

Burkholder, J. B., Curtius, J., Ravishankara, A. R., and Lovejoy, E. R.: Laboratory studies of the homogeneous nucleation of iodine oxides, Atmos. Chem. Phys., 4, 19-34, doi:10.5194/acp-419-2004, 2004.

Burrows, J. P., Hölzle, E., Goede, A. P. H., Visser, H., and Fricke, W.: SCIAMACHY - Scanning Imaging Absorption Spectrometer for Atmospheric Chartography, Acta Astronautica, 35, 445-451, 1995. 
Butz, A., Bösch, H., Camy-Peyret, C., Chipperfield, M. P., Dorf, M., Kreycy, S., Kritten, L., Prados-Román, C., Schwärzle, J., and Pfeilsticker, K.: Constraints on inorganic gaseous iodine in the tropical upper troposphere and stratosphere inferred from balloon-borne solar occultation observations, Atmos. Chem. Phys., 9, 7229-7242, doi:10.5194/acp-9-7229-2009, 2009.

Carpenter, L. J.: Iodine in the Marine Boundary Layer, Chem. Rev., 103, 4953-4962, 2003.

Carpenter, L. J., MacDonald, S. M., Shaw, M. D., Kumar, R., Saunders, R. W., Parthipan, R., Julie, W., and Plane, J. M. C.: Atmospheric iodine levels influenced by sea surface emissions of inorganic iodine, Nature Geosci., 6, 108-111, doi:10.1038/ngeo1687, 2013.

Chameides, W. L. and Davis, D. D.: Iodine: its possible role in tropospheric chemistry, J. Geophys. Res., 85, 7383-7398, 1980.

Chehade, W., Gür, B., Spietz, P., Gorshelev, V., Serdyuchenko, A., Burrows, J. P., and Weber, M.: Temperature dependent ozone absorption cross section spectra measured with the GOME-2 FM3 spectrometer and first application in satellite retrievals, Atmos. Meas. Tech., 6, 1623-1632, doi:10.5194/amt-6-1623-2013, 2013.

Dix, B., Baidar, S., Bresch, J. F., Hall, S. R., Schmidt, K. S., Wang, S., and Volkamer, R.: Detection of iodine monoxide in the tropical free troposphere, P. Natl. Acad. Sci., 110, 2035-2040, doi:10.1073/pnas.1212386110, 2013.

Garland, J. A. and Curtis, H.: Emission of Iodine From the Sea Surface in the Presence of Ozone, J. Geophys. Res., 86, 3183-3186, 1981.

General, S., Bobrowski, N., Pöhler, D., Weber, K., Fischer, C., and Platt, U.: Airborne I-DOAS measurements at Mt. Etna: BrO and OClO evolution in the plume, J. Volcanol. Geoth. Res., 300, 175186, doi:10.1016/j.jvolgeores.2014.05.012, 2015.

Gerlach, T. M.: Volcanic sources of tropospheric ozonedepleting trace gases, Geochem. Geophy. Geosy., 5, Q09007, doi:10.1029/2004GC000747, 2004.

Gliß, J., Bobrowski, N., Vogel, L., Pöhler, D., and Platt, U.: $\mathrm{OClO}$ and $\mathrm{BrO}$ observations in the volcanic plume of Mt. Etna - implications on the chemistry of chlorine and bromine species in volcanic plumes, Atmos. Chem. Phys., 15, 5659-5681, doi:10.5194/acp-15-5659-2015, 2015.

Gómez Martín, J. C., Spietz, P., and Burrows, J. P.: Kinetic and Mechanistic Studies of the $\mathrm{I}_{2} / \mathrm{O}_{3}$ Photochemistry, J. Phys. Chem. A., 111, 306-320, doi:10.1021/jp061186c, 2007.

Gottwald, M. and Bovensmann, H. (Ed.): SCIAMACHY Exploring the Changing Earth's Atmosphere, Earth and Environmental Science, Springer Dordrecht Heidelberg London New York, 2011.

Greenblatt, G. D., Orlando, J. J., Burkholder, J. B., and Ravishankara, A. R.: Absorption Measurements of Oxygen Between 330 and 1140 nm, J. Geophys. Res., 95, 18577-18582, 1990.

Honda, F.: Geochemical study of iodine in volcanic gases. II. Behavior of iodine in volcanic gases, Geochem. Jo., 3, 201-211, 1970.

Honda, F., Mizutani, Y., Sugiura, T., and Oana, S.: A Geochemical Study of Iodine in Volcanic Gases, Bulletin of the Chemical Society of Japan, 39, 2690-2695, 1966.

Hörmann, C., Sihler, H., Bobrowski, N., Beirle, S., Penning de Vries, M., Platt, U., and Wagner, T.: Systematic investigation of bromine monoxide in volcanic plumes from space by using the GOME-2 instrument, Atmos. Chem. Phys., 13, 4749-4781, doi:10.5194/acp-13-4749-2013, 2013.

Hossaini, R., Chipperfield, M. P., Montzka, S. A., Rap, A., Dhomse, S., and Feng, W.: Efficiency of short-lived halogens at influencing climate through depletion of stratospheric ozone, Nature Geosci., 8, 186-190, doi:10.1038/ngeo2363, 2015.

Kern, C., Sihler, H., Vogel, L., Rivera, C., Herrera, M., and Platt, U.: Halogen oxide measurements at Masaya Volcano, Nicaragua using active long path differential optical absorption spectroscopy, Bull. Volcanol., 71, 659-670, doi:10.1007/s00445-008-0252-8, 2009.

Lampel, J., Frieß, U., and Platt, U.: The impact of vibrational Raman scattering of air on DOAS measurements of atmospheric trace gases, Atmos. Meas. Tech., 8, 3767-3787, doi:10.5194/amt-8-3767-2015, 2015.

Lee, C., Kim, Y. J., Tanimoto, H., Bobrowski, N., Platt, U., Mori, T., Yamamoto, K., and Hong, C. S.: High $\mathrm{ClO}$ and ozone depletion observed in the plume of Sakurajima volcano, Japan, Geophys. Res. Lett., 32, 121809, doi:10.1029/2005GL023785, 2005.

Muramatsu, Y. and Wedepohl, K. H.: The distribution of iodine in the earth's crust, Chem. Geol., 147, 201-216, doi:10.1016/S0009-2541(98)00013-8, 1998.

Murphy, D. M. and Thomson, D. S.: Halogen ions and NO+ in the mass spectra of aerosols in the upper troposphere and lower stratosphere, Geophys. Res. Lett., 27, 3217-3220, doi:10.1029/1999GL011267, 2000.

Newhall, C. G. and Self, S.: The volcanic explosivity index (VEI) an estimate of explosive magnitude for historical volcanism, J. Geophys. Res.-Oceans, 87, 1231-1238, doi:10.1029/JC087iC02p01231, 1982.

O'Dowd, C. D. and Hoffmann, T.: Coastal New Particle Formation: A Review of the Current State-Of-The-Art, Environ. Chem., 2, doi:10.1071/EN05077, 2005.

Peters, E., Wittrock, F., Richter, A., Alvarado, L. M. A., Rozanov, V. V., and Burrows, J. P.: Liquid water absorption and scattering effects in DOAS retrievals over oceans, Atmos. Meas. Tech., 7, 4203-4221, doi:10.5194/amt-7-4203-2014, 2014.

Platt, U. and Stutz, J.: Differential Optical Absorption Spectroscopy - Principles and Applications, Springer-Verlag, 2008.

Puentedura, O., Gil, M., Saiz-Lopez, A., Hay, T., Navarro-Comas, M., Gómez-Pelaez, A., Cuevas, E., Iglesias, J., and Gomez, L.: Iodine monoxide in the north subtropical free troposphere, Atmos. Chem. Phys., 12, 4909-4921, doi:10.5194/acp-12-49092012, 2012.

Pundt, I., Pommereau, J.-P., Phillips, C., and Lateltin, E.: Upper Limit of Iodine Oxide in the Lower Stratosphere, J. Atmos. Chem., 30, 173-185, 1998.

Pyle, D. and Mather, T.: Halogens in igneous processes and their fluxes to the atmosphere and oceans from volcanic activity: a review, Chem. Geol., 263, 110-121, doi:10.1016/j.chemgeo.2008.11.013, 2009.

Richter, A.: GOME-2 volcanic $\mathrm{SO}_{2}$ algorithm theoretical basis document, Support to Aviation for Volcanic Ash Avoidance, Norw. Inst. for Air Res., Kjeller, Norway, available at: http://savaa.nilu. no/PublicArchive/tabid/3207/Default.aspx (last access: March 2017), 2009.

Rozanov, V. V., Rozanov, A. V., Kokhanovsky, A. A., and Burrows, J. P.: Radiative transfer through terrestrial atmosphere and ocean: 
Software package SCIATRAN, J. Quant. Spectrosc. Ra., 133, 13-71, doi:10.1016/j.jqsrt.2013.07.004, 2014.

Saiz-Lopez, A., Chance, K., Liu, X., Kurosu, T. P., and Sander, S. P.: First observations of iodine oxide from space, Geophys. Res. Lett., 34, L12812, doi:10.1029/2007GL030111, 2007.

Saiz-Lopez, A., Plane, J. M. C., Baker, A. R., Carpenter, L. J., von Glasow, R., Gómez-Martín, J. C., McFiggans, G., and Saunders, R. W.: Atmospheric Chemistry of Iodine, Chem. Rev., 112, 1773-1804, doi:10.1021/cr200029u, 2012.

Saiz-Lopez, A., Baidar, S., Cuevas, C. A., Koenig, T. K., Fernandez, R. P., Dix, B., Kinnison, D. E., Lamarque, J.-F., RodriguezLloveras, X., Campos, T. L., and Volkamer, R.: Injection of iodine to the stratosphere, Geophys. Res. Lett., 42, 6852-6859, doi:10.1002/2015GL064796, 2015a.

Saiz-Lopez, A., Blaszczak-Boxe, C. S., and Carpenter, L. J.: A mechanism for biologically induced iodine emissions from sea ice, Atmos. Chem. Phys., 15, 9731-9746, doi:10.5194/acp-159731-2015, 2015b.

Saunders, R., Kumar, R., Gomez-Martin, J., Mahajan, A., Murray, B., and Plane, J.: Studies of the formation and growth of aerosol from molecular iodine precursor, Z. Phys. Chem., 224, 10951117, doi:10.1524/zpch.2010.6143, 2010.

Schall, C., Laturnus, F., and Heumann, K. G.: Biogenic volatile organoiodine and organobromine compounds released from polar macroalgae, Chemosphere, 28, 1315-1324, 1994.

Schönhardt, A., Richter, A., Wittrock, F., Kirk, H., Oetjen, H., Roscoe, H. K., and Burrows, J. P.: Observations of iodine monoxide columns from satellite, Atmos. Chem. Phys., 8, 637-653, doi:10.5194/acp-8-637-2008, 2008.

Schönhardt, A., Begoin, M., Richter, A., Wittrock, F., Kaleschke, L., Gómez Martín, J. C., and Burrows, J. P.: Simultaneous satellite observations of $\mathrm{IO}$ and $\mathrm{BrO}$ over Antarctica, Atmos. Chem. Phys., 12, 6565-6580, doi:10.5194/acp-12-6565-2012, 2012.

Snyder, G. T. and Fehn, U.: Origin of iodine in volcanic fluids: ${ }^{129} \mathrm{I}$ results from the Central American Volcanic Arc, Geochim. Cosmochim. Acta, 66, 3827-3838, 2002.

Solomon, S., Garcia, R. R., and Ravishankara, A. R.: On the role of iodine in ozone depletion, J. Geophys. Res., 99, 20491-20499, 1994.

Solomon, S., Ivy, D. J., Kinnison, D., Mills, M. J., Neely, R. R., and Schmidt, A.: Emergence of healing in the Antarctic ozone layer, Science, 353, 269-274, doi:10.1126/science.aae0061, 2016.

Surl, L., Donohoue, D., Aiuppa, A., Bobrowski, N., and von Glasow, R.: Quantification of the depletion of ozone in the plume of Mount Etna, Atmos. Chem. Phys., 15, 2613-2628, doi:10.5194/acp-15-2613-2015, 2015.
Thalman, R. and Volkamer, R.: Temperature dependent absorption cross-sections of $\mathrm{O}_{2}-\mathrm{O}_{2}$ collision pairs between 340 and $630 \mathrm{~nm}$ and at atmospherically relevant pressure, Phys. Chem. Chem. Phys., 15, 15371-15381, doi:10.1039/C3CP50968K, 2013.

Theys, N., Van Roozendael, M., Dils, B., Hendrick, F., Hao, N., and De Mazière, M.: First satellite detection of volcanic bromine monoxide emission after the Kasatochi eruption, Geophys. Res. Lett., 36, L03809, doi:10.1029/2008GL036552, 2009.

Theys, N., De Smedt, I., Van Roozendael, M., Froidevaux, L., Clarisse, L., and Hendrick, F.: First satellite detection of volcanic OClO after the eruption of Puyehue-Cordón Caulle, Geophys. Res. Lett., 41, 667-672, doi:10.1002/2013GL058416, 2014.

Vogt, R., Sander, R., von Glasow, R., and Crutzen, P. J.: Iodine Chemistry and its role in Halogen Activation and Ozone Loss In the Marine Boundary Layer: A Model Study, J. Atmos. Chem., 32, 375-395, 1999.

Volkamer, R., Baidar, S., Campos, T. L., Coburn, S., DiGangi, J. P., Dix, B., Eloranta, E. W., Koenig, T. K., Morley, B., Ortega, I., Pierce, B. R., Reeves, M., Sinreich, R., Wang, S., Zondlo, M. A., and Romashkin, P. A.: Aircraft measurements of BrO, IO, glyoxal, $\mathrm{NO}_{2}, \mathrm{H}_{2} \mathrm{O}, \mathrm{O}_{2}-\mathrm{O}_{2}$ and aerosol extinction profiles in the tropics: comparison with aircraft-/ship-based in situ and lidar measurements, Atmos. Meas. Tech., 8, 2121-2148, doi:10.5194/amt-8-2121-2015, 2015

von Glasow, R., Bobrowski, N., and Kern, C.: The effects of volcanic eruptions on atmospheric chemistry, Chem. Geol., 263, 131-142, doi:10.1016/j.chemgeo.2008.08.020, 2009.

Vountas, M., Rozanov, V. V., and Burrows, J. P.: Ring effect: Impact of rotational Raman scattering on radiative transfer in Earth's atmosphere, J. Quant. Spectrosc. Radiat. Transfer, 60, 943-961, 1998.

Waythomas, C. F., Scott, W. E., Prejean, S. G., Schneider, D. J., Izbekov, P., and Nye, C. J.: The 7-8 August 2008 eruption of Kasatochi Volcano, central Aleutian Islands, Alaska, J. Geophys. Res.-Solid Earth, 115, B00B06, doi:10.1029/2010JB007437, 2010.

Witt, M. L. I., Mather, T. A., Pyle, D. M., Aiuppa, A., Bagnato, E., and Tsanev, V. I.: Mercury and halogen emissions from Masaya and Telica volcanoes, Nicaragua, J. Geophys. Res.-Solid Earth, 113, B06203, doi:10.1029/2007JB005401, 2008.

World Meteorological Organization: Scientific Assessment of Ozone Depletion: 2014, World Meteorological Organization (WMO), Global Ozone Research and Monitoring Project-Report No. 55, World Meteorological Organization, 416 pp., 2014. 